\title{
PENERAPAN PENDEKATAN PROBLEM BASED INSTRUCTION (PBI) BERORIENTASI MODEL PEMBELAJARAN THINK PAIR- SHARE (TPS) DALAM UPAYA MENINGKATKAN MOTIVASI DAN HASIL BELAJAR MAHASISWA
}

\author{
Arwin Arif \\ STKIP Pembangunan Indonesia Makassar \\ e-mail : arwinarif29@gmail.com \\ Herlina \\ STKIP Pembangunan Indonesia Makassar \\ e-mail : Herlina161987@gmail.com
}

\begin{abstract}
Abstrak
Penelitian ini pada dasarnya bertujuan untuk meningkatkan motivasi dan hasil belajar mahasiswa menggunakan penerapan pendekatan Problem Based Instruction (PBI) berorientasi model pembelajaran Think Pair-Share (TPS) pada mata kuliah evolusi. Jenis penelitian ini adalah penelitian tindakan kelas (classroom action). Subyek penelitian ini yaitu mahasiswa program studi pendidikan biologi yang sedang menempuh mata kuliah evolusi. Prosedur penelitian dilaksanakan melalui proses bersiklus yang terdiri atas 4 tahap yaitu perencanaan, pelaksanaan, observasi dan refleksi. Teknik pengumpulan data dalam penelitian ini dilakukan dengan teknik observasi, tes, angket dan dokumentasi. Data yang terkumpul akan di analisis menggunakan teknik persentase, statistik deksriptif dan analisis kualitatif. Dari hasil penelitian ini diperoleh data bahwa untuk motivasi belajar mahasiswa memperoleh rata-rata pada Siklus I sebesar 67,49 dan Siklus II sebesar 80,41 dengan ini menunjukkan peningkatan sebesar 12,92. Untuk hasil belajar mahasiswa memperoleh nilai rata-rata pada Siklus I sebesar 53,69 dan Siklus II sebesar 76,13 menunjukkan peningkatan yang sebesar 22,44. Berdasarkan data tersebut dapat disimpulkan bahwa Penerapan Pendekatan Problem Based Instruction (PBI) berorientasi model pembelajaran Think Pair-Share (TPS) dapat meningkatkan motivasi dan hasil belajar mahasiswa pada mata kuliah evolusi di STKIP Pembangunan Indonesia Makassar.
\end{abstract}

Kata Kunci : Hasil Belajar, Motivasi, Problem Based Instruction (PBI), Think Pair Share (TPS),

\begin{abstract}
This research basically aims to increase student motivation and learning outcomes using the application of the Problem Based Instruction (PBI) approach oriented to the Think Pair-Share (TPS) learning model in the evolution course. This type of research is classroom action research. The subjects of this study were biology education study program students who were taking an evolution course. The research procedure is carried out through a cyclical process consisting of 4 stages, namely planning, implementation, observation and reflection. Data collection
\end{abstract}


techniques in this study were carried out by observation, tests, questionnaires and documentation. The collected data will be analyzed using percentage techniques, descriptive statistics and qualitative analysis. From the results of this study obtained data that for student learning motivation obtain an average in Cycle I of 67.49 and Cycle II of 80.41 with this showing an increase of 12.92. For student learning outcomes obtain an average value in Cycle I of 53.69 and Cycle II of 76.13 shows an increase of 22.44. Based on these data it can be concluded that the Application of the Problem Based Instruction (PBI) approach oriented to the Think Pair-Share (TPS) learning model can increase student motivation and learning outcomes in evolutionary courses at STKIP Indonesia Development Makassar.

Keywords: Learning Outcomes, Motivation, Problem Based Instruction (PBI), Think Pair Share (TPS),

\section{PENDAHULUAN}

Program Studi Pendidikan Biologi Sekolah Tinggi Keguruan dan Ilmu Pendidikan Pembangunan Indonesia (STKIP-PI) Makassar yang menawarkan mata Kuliah Evolusi kepada mahasiswa pada semester ganjil. Mata kuliah ini merupakan mata kuliah yang wajib dengan bobot 2 sks. Pada tahun 2018, perkuliahan Evolusi diikuti oleh mahasiswa berjumlah 260 orang yang terbagi kedalam 9 kelas yakni $\mathrm{VII}_{\mathrm{A}^{-}}$ $\mathrm{VII}_{\mathrm{I}}$ dengan rata-rata jumlah mahasiswa setiap kelas terdiri dari 30 orang. Berdasarkan sistem penilaian dengan kriteria yang telah ditentukan, sebanyak 13\% mahasiswa mendapatkan nilai A, mahasiswa mendapatkan nilai B sebanyak 32\%, Mahasiswa mendapatkan nilai C sebanyak 37\%, mahasiswa mendapatkan nilai D sebanyak $12 \%$ dan mahasiswa mendapatkan nilai E sebanyak 6\%. Beberapa mahasiswa mengambil mata kuliah yang lebih dari satu sebagai upaya untuk perbaikan nilai.

Sehubungan dengan masalah di atas, maka diperlukan suatu terobosan baru dalam pembelajaran yang dapat dipergunakan oleh dosen sebagai dasar untuk melaksanakan kegiatan pembelajaran dengan baik khususnya dalam mata kuliah evolusi sehingga berdampak dalam peningkatkan motivasi dan hasil belajar mahasiswa. Menurut Haling JR (2013), faktor utama yang menentukan mutu pendidikan adalah dosen karena merupakan hal yang dianggap penting dan terdepan dalam menciptakan individu yang unggul. Dosen berhadapan langsung dengan para mahasiswa di kelas melalui proses belajar mengajar. Para pengajar akan menghasilkan mahasiswa yang berkualitas baik secara akademis, keahlian, kematangan emosional, moral dan spiritual. Oleh karena itu, menghasilkan generasi yang siap hidup dengan tantangan kedepannya. 
Oleh karena itu, diperlukan individu yang mempunyai kualifikasi kompetensi dan dedikasi yang tinggi dalam menjalankan tugas dengan baik (Taufik,2010).

Pembelajaran yang dapat diterapkan dalam proses belajar yang dianggap mampu mendorong motivasi serta berpengaruh langsung terhadap hasil belajar mahasiswa adalah Problem Based Instruktion (PBI). PBI adalah jenis pendekatan pembelajaran untuk mahasiswa pada masalah kehidupan nyata, dengan memberikan pengaruh pengembangkan kemampuan berpikir serta pemecahan masalah dan keterampilan intelektual (Lie,2007). Proses pembelajaran memiliki peran yang cukup besar untuk menambah pengalaman belajar dalam kehidupan nyata bagi mahasiswa. Menurut Trianto (2007), menjelaskan bahwa PBI merupakan pendekatan yang menggunakan permasalahan yang jelas dengan maksud untuk menyusun pengetahuan awal mahasiswa, mengembangkan kemanpuan berpikir dan keterampilan berpikir tingkat lebih tinggi, mengembangkan sifat mandiri dan kepercayaan individual. Pendekatan pembelajaran ini dapat digunakan dalam mengaktifkan mahasiswa dalam belajar (Sanjaya,2012). Sedangkan model pembelajaran kooperatif tipe Think Pair-Share merupakan suatu cara yang sangat efektif untuk membuat suasana pola diskusi kelas dengan asumsi bahwa semua kegiatan membutuhkan pengaturan untuk mengontrol kelas secara keseluruhan dan langka kerja yang diberikan di dalam bentuk model ini dapat memberikan mahasiswa lebih banyak untuk berpikir, untuk merespon, dan saling bekerjasama (Djumingin,2011).

Penerapan pendekatan Problem Based Instruction (PBI) berorientasi dengan pembelajaran Think Pair-Share (TPS) mampu memberikan inovasi baru untuk pembelajaran. Adanya orientasi antara pendekatan dengan model pembelajaran kooperatif maka mahasiswa selain aktif di dalam kelas tetapi juga membuat mahasiswa aktif di luar kelas dengan cara mahasiswa secara berkelompok diberikan masalahmasalah yang berhubungan dengan materi pembelajaran, merumuskan masalah dan hipotesis, mengumpulkan data dari berbagai sumber dan menguji hipotesis yang telah dirumuskan secara berkelompok melalui pemaparan materi terhadap teman kelompoknya masing-masing (Sri Wardani,2009). Berkenaan dengan itu timbul suatu keinginan menerapkan pendekatan "Problem Based Instruction (PBI) berorientasi model pembelajaran Think Pair-Share (TPS) dalam upaya meningkatkan motivasi dan hasil belajar mahasiswa pada mata kuliah evolusi”. 


\section{METODOLOGI PENELITIAN}

Jenis penelitian ini adalah penelitian tindakan kelas (classroom action research), dengan menggunakan prosedur yaitu mulai perencanaan, tindakan, observasi, dan refleksi. Subyek dari penelitian ini yaitu mahasiswa jurusan biologi pada mata kuliah evolusi pada semester ganjil (semester tujuh) di kampus STKIP-PI Makassar tahun akademik 2018/2019 yang berjumlah 30 orang mahasiswa. Subyek penelitian diantaranya pendekatan Problem Based Instruction (PBI) berorientasi pembelajaran Think Pair-Share (TPS), motivasi dan hasil belajar mahasiswa. Prosedur penelitian ini sesuai dengan karakter dari Penelitian Tindakan Kelas, penelitian akan dilakukan dalam 2 siklus dimana dalam setiap siklus terdapat 4 tahapan kegiatan mulai dari perencanaan, pelaksanaan, pengamatan, dan refleksi (Sugiono,2010).

Alat pengumpulan data berupa angket tertutup yang digunakan untuk mengumpulkan data tentang motivasi belajar mahasiswa dalam mengikuti perkuliahan pada mata kuliah evolusi dengan memberikan jawaban sesuai indikator yang telah ditetapkan peneliti,Tes hasil belajar dilaksanakan tiap akhir siklus untuk mengetahui sejauhmana pemahaman mahasiswa terhadap materi yang diberikan. dokumentasi dipergunakan untuk mengumpulkan data kegiatan mahasiswa selama proses belajarmengajar di kelas.

Analisis data yang diperoleh untuk motivasi belajar mahasiswa akan di analisis dengan menggunakan cara mempersentasekan nilai yang diperoleh ,menghitung peningkatan motivasi belajar mahasiswa pada setiap siklus dengan memberikan 25 pernyataaan atau pertanyaan. Data hasil belajar mahasiswa dianalisis dengan menghitung setiap rata-rata hasil belajar mahasiswa pada setiap siklus. Penelitian ini menggunakan soal yang berbentuk pilihan ganda (PG) dan uraian. Siklus I serta siklus II terdiri dari 20 soal pilihan ganda (PG) dan 5 soal uraian dan total nilai tertinggi 100 dan terendah 0 . Soal tes dibuat peneliti dengan menggunakan ktiteria yang tekah ditentukan peneliti, bahwa butir soal yang diujikan sesuai dengan yang ada di RPS.

Hipotesis tindakan penerapan pendekatan Problem Based Instruction (PBI) berorientasi model pembelajaran Think Pair-Share (TPS) mampu meningkatkan motivasi dan hasil belajar mahasiswa pada mata kuliah evolusi di jurusan pendidikan biologi STKIP Pembangunan Indonesia Makassar. 


\section{HASIL DAN PEMBAHASAN}

\section{Motivasi Belajar Mahasiswa}

Nilai rata-rata motivasi belajar dari 39 mahasiswa pada mata kuliah evolusi dengan menerapkan pendekatan Problem Based Instruction (PBI) berorientasi model pembelajaran Think Pair-Share (TPS) terjadi peningkatan dari siklus 1 ke siklus 2 , yaitu dari 67,49 menjadi 80,4. Standar deviasi pada siklus 1 yaitu 5,52 dan siklus 2 yaitu 6,42. Nilai varians 30,41 pada siklus 1 dan 41,30 pada siklus 2 . Rentang nilai pada siklus 1 yaitu 24 dan siklus 2 yaitu 31. Nilai terendah yang diperoleh mahasiswa untuk motivasi belajar mahasiswa pada siklus 1 adalah 54 dan nilai tertinggi 78. Sedangkan pada siklus 2, nilai motivasi belajar mahasiswa meningkat dengan nilai terendah 67 dan nilai tertinggi 98. Penjabaran nilai motivasi belajar mahasiswa setelah dikelompokkan dalam kategori sangat tinggi, tinggi, cukup, rendah, dan sangat rendah.

Tabel 1. Distribusi Frekuensi dan Kategorisasi nilai Motivasi Belajar Mahasiswa dengan Penerapan pendekatan Problem Based Instruction (PBI) berorientasi model pembelajaran Think Pair-Share (TPS)

\begin{tabular}{llllll}
\hline \multirow{2}{*}{ Nilai } & \multirow{2}{*}{ Kriteria } & \multicolumn{2}{l}{ Frekuensi } & \multicolumn{2}{l}{ Persentase (\%) } \\
\cline { 3 - 6 } & & Siklus 1 & Siklus 2 & Siklus 1 & Siklus 2 \\
\hline $105 \leq \mathrm{M}<125$ & Sangat Tinggi & 0 & 10 & 0 & 25,64 \\
$85 \leq \mathrm{M}<105$ & Tinggi & 18 & 28 & 46,15 & 71,79 \\
$65 \leq \mathrm{M}<85$ & Cukup & 21 & 1 & 53,85 & 2,57 \\
$45 \leq \mathrm{M}<65$ & Rendah & 0 & 0 & 0 & 0 \\
$25 \leq \mathrm{M}<45$ & Sangat Rendah & 0 & 0 & 0 & 0 \\
\hline Jumlah & & $\mathbf{3 9}$ & $\mathbf{3 9}$ & $\mathbf{1 0 0}$ & $\mathbf{1 0 0}$ \\
\hline
\end{tabular}

Sumber : Data hasil penelitian (2018)

Berdasarkan tabel 1 diatas diperoleh Distribusi Frekuensi dan Kategorisasi nilai Motivasi Belajar Mahasiswa yaitu pada siklus 1 kriteria sangat tinggi 0 orang atau $0 \%$, tinggi 18 orang atau 46,15\%, cukup 21 orang atau 53,85\%, rendah dan sangat rendah 0 orang atau 0\%. Pada siklus 2 kriteria sangat tinggi 10 orang atau 25,64\%, tinggi 28 orang atau $71,79 \%$, cukup 1 orang atau $2,57 \%$, rendah dan sangat rendah 0 orang atau $0 \%$.

Hasil dari distribusi dan frekuensi motivasi belajar perolehan mahasiswa antara siklus 1 dan siklus 2 dengan pendekatan Problem Based Instruction (PBI) berorientasi 
model pembelajaran Think Pair-Share (TPS) terjadi peningkatan yang cukup signifikan dengan melihat dilihat penggunaan persamaan normalisasi $\mathrm{N}$-Gain, hasil perhitungan tersebut dapat dilihat pada Tabel 2 berikut.

Tabel.2 Penjabaran nilai Selisih (Gain Score) Motivasi Belajar Mahasiswa dengan penerapan pendekatan Problem Based Instruction (PBI) berorientasi model pembelajaran Think Pair-Share (TPS)

\begin{tabular}{clll}
\hline Interval Nilai & Frekuensi & Persentase $(\%)$ & Kategori \\
\hline $0 \leq \mathrm{N}-\mathrm{g}<0,3$ & 14 & 35,90 & Rendah \\
$0,3 \leq \mathrm{N}-\mathrm{g}<0,7$ & 21 & 53,85 & Sedang \\
$0,7 \leq \mathrm{N}-\mathrm{g} \leq 1,0$ & 4 & 10,25 & Tinggi \\
\hline
\end{tabular}

Berdasarkan tabel.2 diatas menunjukkan besarnya peningkatan nilai motivasi belajar mahasisa dengan normalisasi Gane pada siklus 1 dan siklus 2 dengan pendekatan Problem Based Instruction (PBI) berorientasi model pembelajaran Think Pair-Share (TPS) hasil yang diperoleh adalah bahwa sebagian besar mahasiswa, yakni sebesar $53,85 \%$ mengalami peningkatan nilai motivasi belajar mahasiswa pada kategori sedang. Hasil analisis data yang telah dilakukan nilai rata-rata motivasi belajar mahasiswa, dapat diketahui bahwa motivasi belajar mahasiswa dengan penerapan pendekatan Problem Based Instruction (PBI) Berorientasi Model Pembelajaran Think Pair-Share (TPS) dari siklus 1 ke siklus 2 memperoleh peningkatan yang cukup signifikan. Menurut Kunandar (2007), mengatakan bahwa pembelajaran dengan penerapan pendekatan Problem Based Instruction (PBI) Berorientasi Model Pembelajaran Think Pair-Share (TPS) dapat memberikan dorongan untuk belajar dan berdiskusi dengan teman kelompoknya secara intensif, sedangkan dosen hanya bertindak sebagai pengarah serta penguat yakni menjawab pertanyaan mahasiswa jika ada yang kurang di pahami oleh mahasiswa, dosen bertindak sebagai pengatur yakni mengkondisikan kelas dengan dengan cara berkeliling pada setiap kelompok.

Setiap mahasiswa mempresentasekan hasil kerja kelompok di depan kelas, kemudian teman yang lain mengajukan beberapa pertanyaan terkait dengan materi pelajaran dan mahasiswa tersebut menjawab dan memberikan jawaban berdasarkan apa yang mereka pahami dari materi yang telah dipelajari sebelumnya (Sahabuddin,2011). Sementara mahasiswa hanya memberikan setiap jawaban dari mahasiswa dan menuntuntunya dengan argument atau jawaban yang sesuai pertanyaan. Hal ini sesuai 
dengan yang diungkapkan oleh Bobbi DePorter yang menyatakan bahwa manfaat dari pendekatan Problem Based Instruction (PBI) Berorientasi Model Pembelajaran Think Pair-Share (TPS)`yaitu fleksibel, dapat memusatkan perhatian, meningkatkan pemahaman, menjadikan lebih kreatif dan menyenangkan.

\section{Hasil Belajar Mahasiswa}

Hasil belajar yang diperoleh mahasiswa pada siklus 1 dengan menggunakan Pendekatan Problem Based Instruction (PBI) berorientasi model pembelajaran Think Pair-Share (TPS) menunjukkan nilai terbaik adalah 68 dan nilai rendah adalah 32. Adapun nilai rata-rata yang diperoleh adalah 53,69, sedangkan hasil belajar mahasiswa pada siklus 2 dengan menggunakan Pendekatan Problem Based Instruction (PBI) berorientasi model pembelajaran Think Pair-Share (TPS) menunjukkan nilai terbaik adalah 90 dan nilai rendah adalah 60. Rata-rata yang diperoleh pun mengalami peningkatan, yakni menjadi 76,13.

Berdasarkan keseluruhan nilai hasil belajar di dapatkan mahasiswa dengan menggunakan Pendekatan Problem Based Instruction (PBI) berorientasi model pembelajaran Think Pair-Share (TPS) maka nilai hasil belajar mahasiswa dapat di kelompokkan dalam tabel 3, yakni penjabaran frekuensi dan pengkategorian hasil belajar siswa sebagai berikut.

Tabel.3 Distribusi Frekuensi dan Persentase Hasil Belajar Siswa yang Diajar dengan Pendekatan Problem Based Instruction (PBI) berorientasi model pembelajaran Think Pair-Share (TPS)

\begin{tabular}{llllll}
\hline \multirow{2}{*}{ Interval Nilai } & \multirow{2}{*}{ Kategori } & \multicolumn{2}{l}{ Frekuensi } & \multicolumn{2}{l}{ Persentase (\%) } \\
\cline { 3 - 6 } & & Siklus 1 & Siklus 2 & Siklus 1 & Siklus 2 \\
\hline $85-100$ & Sangat Tinggi & 0 & 8 & 0 & 20,51 \\
$65-84$ & Tinggi & 6 & 26 & 15,38 & 66,67 \\
$55-64$ & Sedang & 17 & 5 & 43,59 & 12,82 \\
$35-54$ & Rendah & 13 & 0 & 33,33 & 0 \\
$0-34$ & Sangat Rendah & 3 & 0 & 7,69 & 0 \\
\hline & Jumlah & 39 & 39 & 100,00 & 100,00
\end{tabular}

Sumber : Data hasil penelitian (2018)

Tabel.3 diatas memperlihatkan nilai hasil belajar dari 39 mahasiswa, siklus 1 dan siklus 2 diajar dengan menggunakan Pendekatan Problem Based Instruction (PBI) berorientasi model pembelajaran Think Pair-Share (TPS) pada mata kuliah evolusi. 
Berdasarkan data tersebut diketahui bahwa pada siklus 1 penerapan Pendekatan Problem Based Instruction (PBI) berorientasi model pembelajaran Think Pair-Share (TPS), dari 39 mahasiswa persentase jumlah yang berada pada kategori sangat rendah adalah 7,69\%, kategori rendah adalah 33,33\%, kategori sedang adalah 43,59\%, kategori tinggi adalah 15,38\%, dan kategori sangat tinggi adalah 0\%. Pada siklus 2 penerapan pendekatan Problem Based Instruction (PBI) berorientasi model pembelajaran Think Pair-Share (TPS), persentase jumlah mahasiswa pada kategori sangat rendah dan rendah adalah $0 \%$, kategori sedang adalah $12,82 \%$, kategori tinggi adalah $66,67 \%$, dan kategori sangat tinggi adalah $20,51 \%$.

Data tentang distribusi dan frekuensi perolehan mahasiswa siklus 1 dan siklus 2 diajar dengan memperlihatkan pendekatan Problem Based Instruction (PBI) berorientasi model pembelajaran Think Pair-Share (TPS) diperkuat oleh peningkatan nilai motivasi belajar mahasiswa untuk menggunakan persamaan normalisasi $N$-Gane. Peningkatan tersebut dapat dilihat pada tabel 4 berikut.

Tabel 4. Distribusi Nilai Selisih (Gain Score) Motivasi Belajar Mahasiswa dengan penerapan pendekatan Problem Based Instruction (PBI) berorientasi model pembelajaran Think Pair-Share (TPS)

\begin{tabular}{rlll}
\hline Interval Nilai & Frekuensi & Persentase $\mathbf{( \% )}$ & Kategori \\
\hline $0 \leq \mathrm{N}-\mathrm{g}<0,3$ & 8 & 20,51 & Rendah \\
$0,3 \leq \mathrm{N}-\mathrm{g}<0,7$ & 23 & 58,98 & Sedang \\
$0,7 \leq \mathrm{N}-\mathrm{g} \leq 1,0$ & 8 & 20,51 & Tinggi \\
\hline
\end{tabular}

Berdasarkan tabel 4 diatas memperlihatkan besarnya peningkatan nilai hasil belajar mahasiswa dengan normalisasi Gane pada siklus 1 dan siklus 2 dengan menggunakan penerapan pendekatan Problem Based Instruction (PBI) berorientasi model pembelajaran Think Pair-Share (TPS). Hasil yang diperoleh adalah bahwa sebagian besar mahasiswa, yakni sebesar 58,97\% mengalami peningkatan nilai hasil belajar pada kategori sedang.

Untuk mengetahui tingkat ketuntasan hasil belajar pada mahasiswa siklus 1 dan siklus 2 dengan penerapan pendekatan Problem Based Instruction (PBI) berorientasi model pembelajaran Think Pair-Share (TPS). dapat dilihat pada tabel 5. dibawah ini : 
Tabel 5 Ketuntasan Hasil Belajar Mahasiswa

\begin{tabular}{llllll}
\hline \multirow{2}{*}{ Interval Nilai } & \multirow{2}{*}{ Kategori } & Srekuensi & \multicolumn{2}{c}{ Persentase (\%) } \\
\cline { 3 - 6 } & Siklus 1 & Siklus 2 & Siklus 1 & Siklus 2 \\
\hline $0-69$ & Tidak Tuntas & 34 & 11 & 87,18 & 28,21 \\
$70-100$ & Tuntas & 5 & 28 & 12,82 & 71,79
\end{tabular}

Berdasarkan tabel 5 diatas menunjukkan bahwa adanya peningkatan frekuensi dan ketuntasan hasil belajar mahasiswa dari siklus 1 yang tidak tuntas 34 orang dengan persentase $87,18 \%$ dan tuntas 5 orang dengan persentase $12,82 \%$. Sedangkan pada siklus 2 yang tidak tuntas 11 orang dengan persentase $28,21 \%$ dan tuntas 28 orang dengan persentase $71,79 \%$. Dari 39 orang mahasiswa yang mengikuti tes hasil belajar melalui penerapan pendekatan Problem Based Instruction (PBI) berorientasi model pembelajaran Think Pair-Share (TPS) 71,79\% memperoleh nilai diatas KKM yang ditentukan yaitu 70,00 namun tidak melebihi ketuntasan klasikal 85\% yang telah ditentukan hal ini bisa diatasi dengan melakukan remedial agar ketuntasan klasikan tercapai bahkan melebihi itu.

Dari data yang telah di analisis di atas memperlihatkan hasil belajar biologi mahasiswa yang dibelajarkan dengan penerapan pendekatan Problem Based Instruction (PBI) berorientasi model pembelajaran Think Pair-Share (TPS) dari siklus 1 ke siklus 2 memberikan peningkatan yang signifikan. Menurut (Sardiman,2011) mengatakan bahwa pendekatan Problem Based Instruction (PBI) berorientasi model pembelajaran Think Pair-Share (TPS) menekankan pada daya ingat dan kerja sama kelompok mahasiswa sehingga mahasiswa yang daya ingatnya kurang maka akan mengalami kesulitan belajar ketika mahasiswa hendak mengulangi pelajarannya dirumah karena catatannya hanya berisi inti dari pokok bahasan dari materi yang diajarkan, dengan kata lain bahwa penjelasan dari inti pokok bahasan tidak dicatat oleh mahasiswa .

Menurut Sinulingga dan Josevina dalam (Paul, E \& Don, K,2012), selain memiliki beberapa kelebihan diantaranya permasalahan yang disajikan terbuka, mahasiswa berkelompok untuk menanggapi, dapat melatih mahasiswa untuk saling bekerjasama dalam diskusi, sangat cocok untuk mengulang kembali pengetahuan awal mahasiswa, pembelajaran dengan pendekatan Problem Based Instruction (PBI) berorientasi model pembelajaran Think Pair-Share (TPS) juga memiliki kekurangan sebagaimana yang diungkapkan oleh Naidra dalam (Sudjana,2010), yaitu banyak 
membutuhkan waktu, sulit mengalokasikan waktu,tuntutan bagi mahasiswa terlalu membebani.Sehingga dapat diberikan kesimpulan bahwa penerapan pendekatan Problem Based Instruction (PBI) berorientasi model pembelajaran Think Pair-Share (TPS) dalam meningkatkan motivasi, hasil belajar sangat efektif karena dapat memberikan peningkatan yang cukup signifikan dari siklus 1 dan siklus 2 dalam proses pembelajaran.

\section{SIMPULAN}

Berdasarkan hasil penelitian ini, diperoleh data bahwa untuk motivasi belajar mahasiswa memperoleh rata-rata pada Siklus I sebesar 67,49 dan Siklus II sebesar 80,41 dengan ini menunjukkan peningkatan sebesar 12,92. Untuk hasil belajar mahasiswa memperoleh nilai rata-rata pada Siklus I sebesar 53,69 dan Siklus II sebesar 76,13 menunjukkan peningkatan yang sebesar 22,44. Berdasarkan data tersebut dapat disimpulkan bahwa Penerapan Pendekatan Problem Based Instruction (PBI) berorientasi model pembelajaran Think Pair-Share (TPS) dapat meningkatkan motivasi dan hasil belajar mahasiswa pada mata kuliah evolusi di STKIP Pembangunan Indonesia Makassar.

\section{UCAPAN TERIMA KASIH}

Ucapan terimah kasih diberikan kepada Ketua STKIP Pembangunan Indonesia dalam hal ini Dr. Muh Yunus, M.Pd yang telah memberikan masukan dan kesediaan mengarahkan penelitian ini, Ketua Jurusan Pendidikan Biologi, Teman-teman dosen jurusan pendidikan biologi serta team dalam penelitian dan tak terlupakan istri dan anak tercintah yang senantiasa memberikan motivasi serta semangat sehingga mampu menyelesaikan penelitian ini dengan baik.

\section{DAFTAR PUSTAKA}

Haling JR,(2013), Belajar dan Pembelajaran. Makassar: Badan Penerbit UNM.

Kunandar,(2007),Guru Profesional Implementasi Kurikulum Tingkat Satuan Pendidikan (KTSP) dan Sukses dalam Sertifikasi Guru. Jakarta: PT. Raja Grafindo Persada. 
Lie,(2007),Cooperative Learning: "Mempraktekkan Cooperative Learning di dalam Ruang-Ruang Kelas”. Jakarta: Gramedia Widiasarana Indonesia.

Paul, E \& Don, K, (2012). Strategi dan Model Pembelajaran. Jakarta: Permata Puri Media.

Sahabuddin ,(2011), Mengajar dan Belajar. Makassar : Badan Penerbit UNM

Sanjaya, (2012), Strategi Pembelajaran Berorientasi Standar Proses Pendidikan. Jakarta: Kencana Prenada Media Group.

Sardiman, (2011), Interaksi \& Motivasi Belajar Mengajar. Jakarta: Rajawali Pers.

Sri Wardani, (2009), Peningkatan Hasil Belajar Siswa Melalui Pendekatan Keterampilan Proses Sains Berorientasi Problem-Based Instruction. Skripsi diterbitkan. Jurusan FMIPA, Universitas Negeri Semarang

Sudjana,(2010), Penilaian Hasil Proses Belajar Mengajar. Bandung:Tarsito

Sugiono,(2010), Metode penelitian pendidikan: pendekatan kuantitatif, kualitatif, dan $R \& D$..Bandung: Alfabeta

Taufiq, (2010). Inovasi Pendidikan Melalui Problem Based Learning. Jakarta: Prenana Media Grup.

Trianto, (2007). Model-model Pembelajaran ilnovatif berorientasi kontruktivistik. Jakarta: Prestasi Pustaka. 